\title{
Art: A Source of Visual Communication
}

\author{
Farah Khan ${ }^{1,2^{*}}$ \\ ${ }^{1}$ Research Scholar of PhD Fine Arts (Studio Practice) at LCWU \\ ${ }^{2}$ Assistant Professor of Visual Arts at the Institute of Visual Arts \& Design, LCWU \\ Received 15 Sept 2018, Accepted 20 Nov 2018, Available online 22 Nov 2018, Vol.6 (Nov/Dec 2018 issue)
}

\begin{abstract}
Art is a fundamental part of human life. The language of art is the most powerful language one can understand beyond the barriers of communication, art provides an open forum for expressiveness. Since pre-historic time it has been observed as a mechanism of communication with each other. It has been analyzed that people throughout history used it for expressing their thoughts, beliefs, philosophies, fears and spiritual connections. Artists from all regions of the world have documented their voice through this medium of expression while focusing on the contemporary issues concerning their own time. In the contemporary age, art is observed as the most powerful tool for voicing the inward experiences of the artist. It is also being utilized for responding back to the society. Artists are free to express what they perceive individually and in what way they want the masses to conceive out of it. They are raising questions and analyzing the political and social scenario in their own visual idiom. In this manner, Pakistani artists are equally participating in raising their voice in visual form to communicate their experiences and challenges they are facing in the contemporary world. They are also providing answers to the prevailing chaos (globally and especially in Pakistan).
\end{abstract}

Keywords: Art, communication, artists, pre-historic time, contemporary age, Pakistan.

\section{Introduction}

Art is meant for communication and it shares an open dialogue with the viewers. It has the most powerful language one can understand beyond any barrier. Art provides an open forum for expressiveness. The language of art can never be calculated in terms of its wave length, it is immensely vast which could be compared with a yawning sea having underlying multi layers of growth, life and existence, that also delivers a story of its own kind. It offers deep horizons beyond the limitations of any blockade. It interprets the soul nature of everything visible or veiled that could be experienced even through transcendentalism.

Art is actually an imitation of the inner and the outer world around the creator, it is innate within every human being, and the connection with nature has different means of expressiveness. As Plato said "Art is imitation, and artist is thirdly removed from nature". ${ }^{1}$ Every form of art is actually the interpretation of nature that serves as the foremost root or line of inquiry. As Baba Bulhay Shah proclaims "Ik nuktay which gal mukdi aay", so the story and its interpretation lies under the basic question of investigation, that contains a complete world of its own

*Corresponding author's ORCID ID: 0000-0002-1034-5374 DOI: https://doi.org/10.14741/ijmcr/v.6.6.11

${ }^{1}$. Shahida Manzoor, interview by Farah Khan, $4^{\text {th }}$ November, 2015. with immensely wide prospects. ${ }^{2}$ It depends on the creator of artwork in which direction he/she wants the viewers to visualize the underlying essence. Reason is always there behind the conception of every art form, and this reason unfolds the hidden narrative account of the actual picture.

Since nineteenth century, the influential debate regarding the landscape of art has concerned more with the purposefulness behind the production of art rather than the concept of beautification. " "In ancient times, Aristotle proclaims that the ethical function is disclosed by whatever reveals character in art. It is a complete body of language that discloses different characters". ${ }^{4}$ An art work is meant to communicate, it expresses about something directly or indirectly. It focuses on a story and narrates its subject matter in its own way. Our information in addition to the related knowledge of the subject and proclamation with art is mainly dialogical. ${ }^{5}$

Talking about art it could not be argued that who is the biggest creator of art? No doubt, God is the chief creator of everything around the globe, whatever he has

\footnotetext{
2. Arif Khan, interview by Farah Khan, $24^{\text {th }}$ February, 2016.

3. Thomas Buser. Experiencing Art Around Us $2^{\text {nd }}$ Edition (London: Wards worth Thomson Learning, 2006), 15.

4 . Ibid, 16.

5. Katy Macleod. Lin Holdridge. Ed. Thinking through Art: Reflections on Art as Research (New York: Routledge, 2006), 22-23.
} 
created in the natural world is also associated with a story. A story of mankind, being in the world they have to prepare themselves for the afterlife in the celestial world. It is commonly believed that the universe was conceived by God through a word Kun (to be). This universe created by the God is rooted with a complete meaningful story. In the same context the language of art apart from words, sounds, and forms of letters is primarily an amalgamation of concepts and a transmittable thread of thoughts.

No doubt, the gist of art is meant for all, whether from any diversified community, religion or region. The general understanding of the concept of art, to some extent is restricted to only visual imagery, though realistically each and every act of a human being is representing something that also falls under the umbrella of art. Well, there is always a generalized idea mentioning that anything which is produced with skillful exercise falls under the umbrella of art. Skills and execution became more important here rather than the inclusion of aesthetic sensibility.

At this point, to understand the core underlying root it is important to define art and fine arts with reference to this context. There is always a clear and well-defined line of separation between the understanding of art and fine arts. Fine art is a broader term for the appreciation of aesthetically creative products shaped by human beings. Fine Arts has five branches (further divided in different sections), these includes painting, sculpture, architecture, literature and music. ${ }^{6}$ Besides these time arts or performing arts includes drama, theatre, acting, sound and light, these are the offshoots of fine arts. In the contemporary age parameters of fine arts have widened beyond expectation where digital art is also playing a vital role for the enhancement of aesthetic sensibility and for the means of global communication. Each of these mediums is meant for communication with underlying narratives and stories. Elements of story include character, setting, concept, plot and point of view and all of these are present in all art forms in general. "It is important to gain some familiarity with subjects as history, philosophy, and the arts to understand ourselves and our society in a true sense. The real worth of art works lies in its capability to express something momentous in a rational and distinctive manner. An important work of art is free from the restrictions of time, region, and language". ${ }^{7}$

Since Paleolithic age art has been used as a strong tool of visual communication for giving messages and through this act history has been recorded that unfolds many layers of meanings and human existence. Human beings started thinking through their created art works. The entire philosophy of their beliefs and concerns have been documented in this form with pleasing manner. These remains in the form of art provide the archeologists and scientists numerous ways to solve the underground

\footnotetext{
${ }^{6}$. Shahida Manzoor, interview by Farah Khan, $4^{\text {th }}$ November, 2015.

7. G.M. Pinciss. Marlies K. Danziger. Peter Basquin. Wayne R. Dynes. Explorations in the Arts: An introduction to the Humanities (New York: Holt, Rinehart and Winston, 1985), 4.
}

mystery. The history of ancient civilizations, their religious and cultural norms, beliefs, ways of living, socio-political environment etc. all have been identified through the lens of art they have left behind. The remains of their art and architecture proved to be a complete documentation of their life styles and values.

Undoubtedly, art and its history help in understanding different cultures and societies by tracing the development of different forms of art through the study of ancient civilizations. Art history is mainly concerned with the study of history, architectural remains and meaning of works of art as the products of different cultures. Art has remained throughout the history as the main unifying factor that existed throughout the ages in diverse cultures of the world. Analysis of the outcome of time, place and cultures plays significant role in the study of the value and meaning of works of art. They also help in tracing the expansion of different forms of art.

Artist being the creator of art generates stories out of his resourceful experiences. His pure flight of imagination, inclusion of different experiences guides the viewers to think with broad vistas. This language contains a wideranging expression of its own. In a fundamental sense, art is part of a process of communication between artists and their audience. "Artist is the initiator in this communication process, the audience acts as receivers; they can experience the event in the form of art singly". The fundamental purpose of art is to educate, it has the power to teach a complete society or a nation. Since classical times, it has been observed that different philosophers have claimed that the additional function of art is to enhance moral or social structure for the sake of betterment in a society. "The ancient Roman poet Horrace summarized in the maxim that art should both teach and delight. In many past cultures, art has been closely involved with communicating political and religious concepts". ${ }^{9}$ While reading the history of art we can easily understand the prevailing scenario of the world and the ups and downs it has witnessed.

Since the creation of the world and mankind, art has been practiced under the umbrella of multi- dimensional aspects. In the Paleolithic age artists used to decorate the surface of the caves with the representation of animals mostly of those he used to hunt and his life was dependent on (fig 1), these paintings are supposed to be used for magical functions as well. They are also communicating the underlying philosophy of the makers.

Besides these, the references of small figurines found from the Paleolithic age were also utilized for some magical properties, these are supposed to be the mother goddesses (fig 2) that validates their beliefs in super natural powers. Moving from the Paleolithic age, the story of human development and intellectual growth was well preserved in the visual art forms created under

8. Ibid, 10

9. G.M. Pinciss. Marlies K. Danziger. Peter Basquin. Wayne R. Dynes. Explorations in the Arts: An introduction to the Humanities (New York: Holt, Rinehart and Winston, 1985), 11. 
different civilizations of the world such as Mesopotamian Civilization, Indus Valley Civilization, Egyptian Civilization, Greco-Roman Civilization etc. The marvels and wonders done by the people of these civilizations could be placed at the pinnacle of human intellectual approach, all the art forms left by these people provides the narrative account about their beliefs and communicates their philosophies about life.

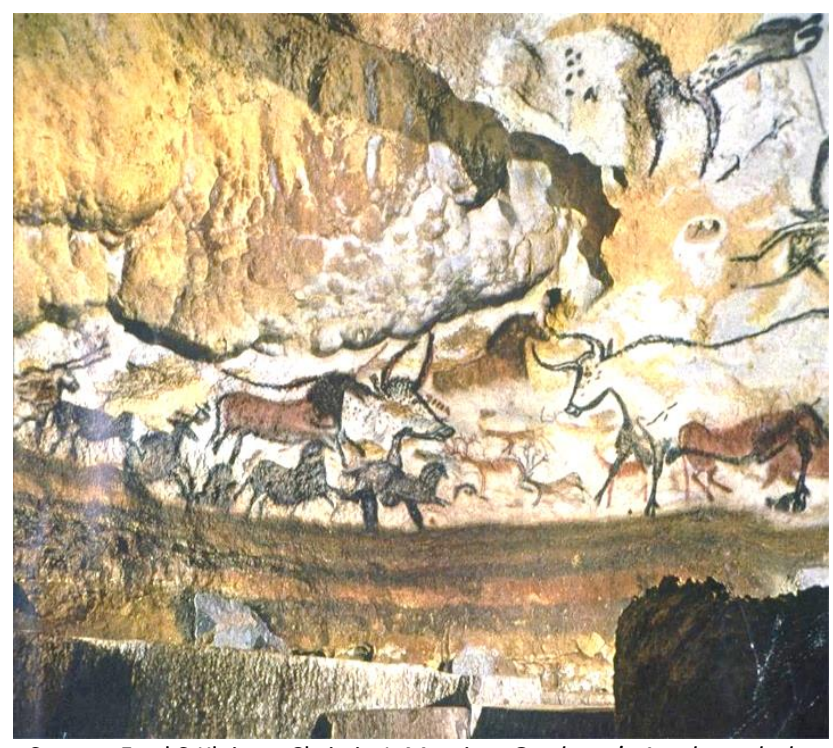

Source: Fred S. Kleiner, Christin J. Mamiya. Gardener's Art through the Ages $13^{\text {th }}$ Ed (New York: Thomson Wordsworth, 2005), 21.

Figure 1 Hall of the Bulls from Lascaux cave, France. (c. 15,000-13, 000 BC). 11'6"long
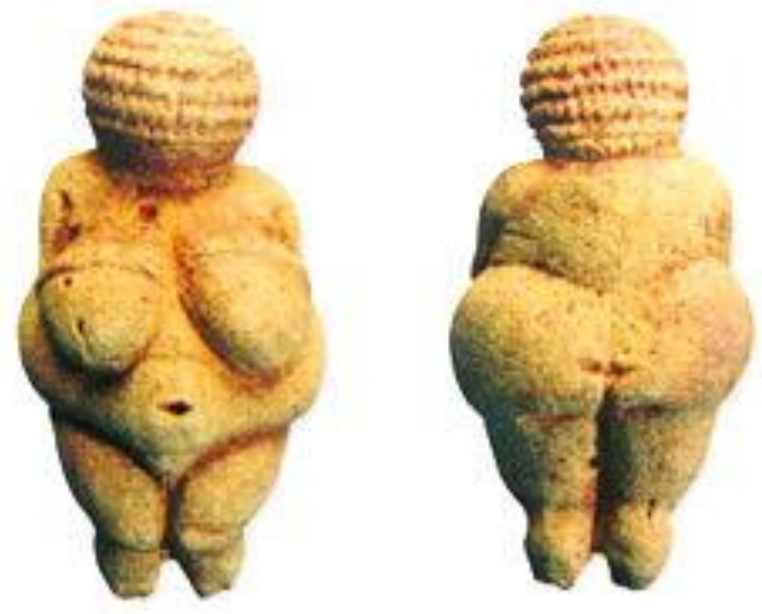

Source: http://4.bp.blogspot.com/-

RCdkH573Sow/T6KpmtoJPel/AAAAAAAABXk/QTbYgfOBgZU/s400/venus -de-willendorf.jpg (accessed on 29th, April, 2014)

Figure 2 Venus of Willendorf from Austria (c. 28,000$25,000 \mathrm{BC}$ ). Limestone, height $43 / 8$-inch

South Asian history is also immensely vast in this context, starting from Indus Valley Civilization till to date with the inclusion of Indian, Ashokan, Buddhist, Jain, and Gandharan art, these also directed towards different schools of thought and narrates the cultural, sociopolitical and religious account. The history of art and architectural marvels is rich in terms of execution. The Ashokan pillars provide the references of their dogma about law in motion (fig 3).

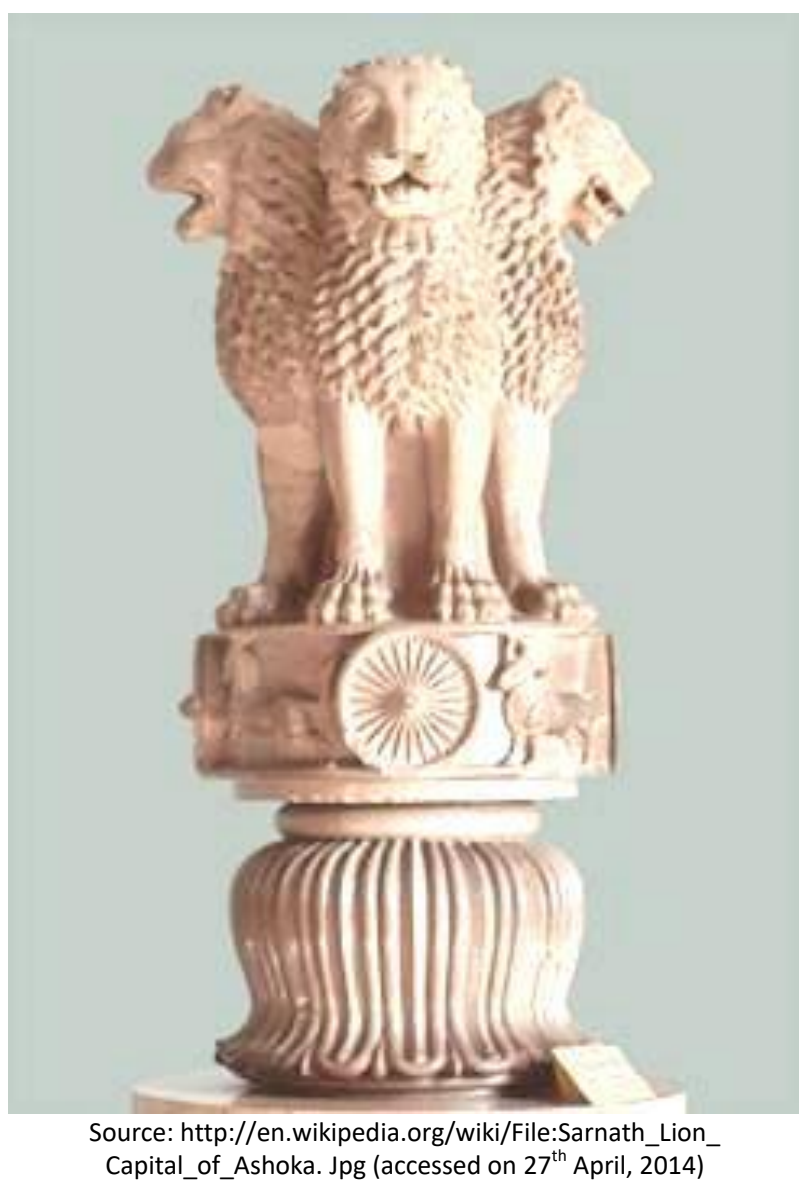

Figure 3 Sarnath Lion Temple of Ashoka,Uttar Pradesh India

The relics of Buddha conserved in the form of stupas are also flavored with the stories related with the life of Buddha. Jataka stories provides a comprehensive interpretation of their philosophical insight (fig 4). Hindu temples exclusively ornamented with sculptures of Indian deities, nayak and nayakas, deva and Devadasis (fig 5) all are representatives of their religious connotation. Hinduism is a religion, diversified in itself because of its varied expressions. "It is the predominant and indigenous religious tradition of the Indian Subcontinent". ${ }^{10}$ It has been mentioned in the Vastu Sutra Upanishad that "from the knowledge of art arises divine knowledge, and such knowledge leads to liberation. This liberation is truly the essence of the knowledge of art. The one, who realizes this, attains liberation, nirvana". ${ }^{11}$

10. http://en.wikipedia.org/wiki/Hinduism\#cite_note-trad-2. (accessed on $22^{\text {nd }}$ April, 2014)

${ }^{11}$. Alka Pande. Master Pieces of Indian Art (New Delhi: Roli and Janssen, 2004), 15. 


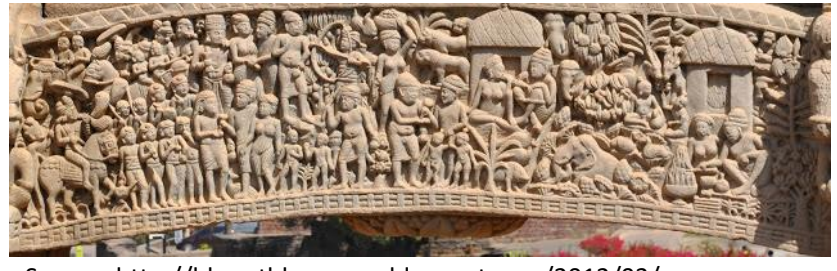

Source: http://bharathkumaran.blogspot.com/2012/03/you-guys-areobsessed-remarked-aussie.html (accessed on 29th, April, 2015)

Figure 4 Jataka tale of Vasantara reiterating the importance of sacrifice, Northern Gateway of Sanchi Stupa.

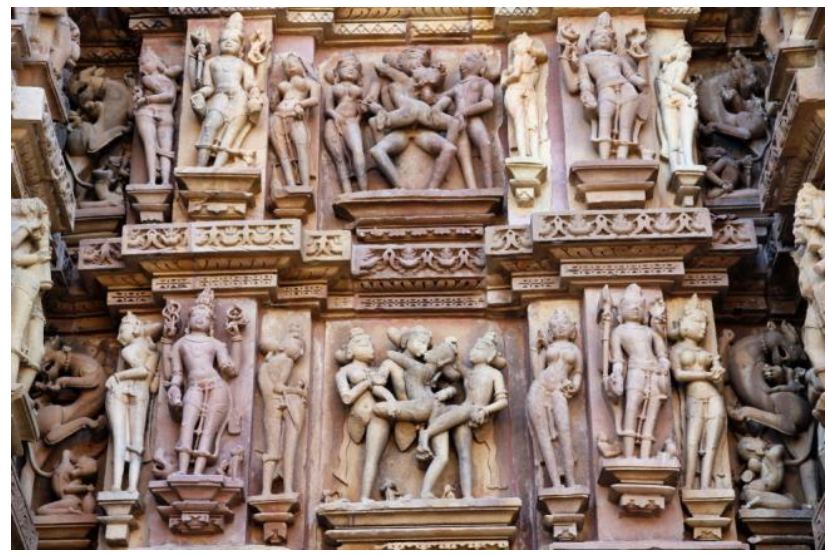

Source: http://www.mariusztravel.com/photos/photos213.php (accessed on 29th, April, 2015)

Figure 5 Deva and Devadasis executed in sculptural form at Khajurao Temple, India.

In the history of Sub-continent, Mughal rulers have also left resourceful insight of their faith and philosophy, they have also preserved the story of their times in the form of art and architecture. The miniature paintings of Mughal period also provide the entire account of their customs and traditions (fig 6). That also provides a complete documentation of their living style. The enormously decorated architectural remains unfold their desire to remain on the earth as the superior ones like that of Egyptian pharaohs, till the end of the world through their built splendid architectural monuments (fig 7). The story of Indian sub-continent is vast in terms of narrative version, and the chain of connectivity is still in progress in the contemporary age. In the current scenario the prime objectives of electronic media in India is to promote their culture and communicate with the global world at an open forum. Indian art, drama, literature, music, dance, even cartoons all reveals their deep association with religious beliefs. They are predominantly using the religious stories and intend to promote their ideologies and philosophies related to Hinduism through different mediums of art. In general, their art is a reflection of their beliefs, culture and traditions.

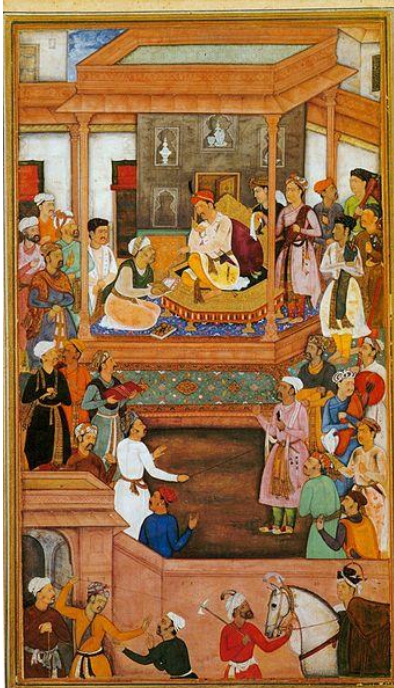

Source: http://commons.wikimedia.org/wiki/File:AbulFazIPresenting Akbarnama.jpg (accessed on $1^{\text {st }}$ May, 2015)

Figure 6 Abul Fazl presenting Akbar Nama

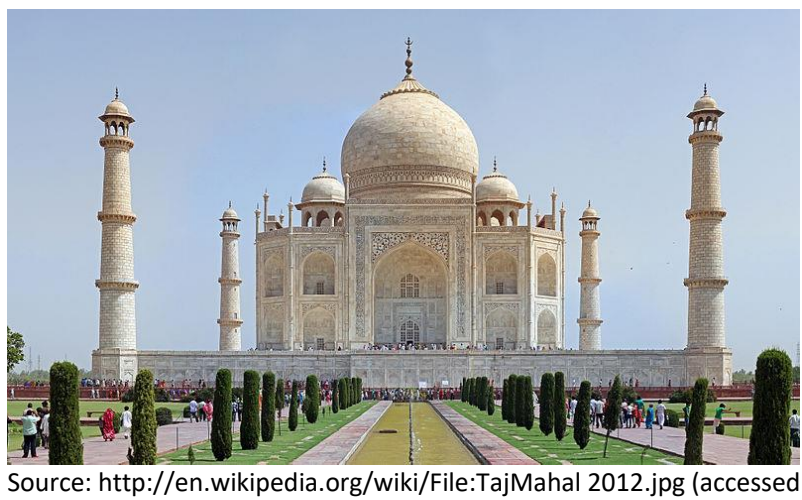
on $1^{\text {st }}$ May 2015)

Figure 7 Taj Mahal at Agra, India 1632-1653A.D.

Besides South Asia, throughout the world phases of human existence, development and the periods of turmoil have also been documented in the language of art in all regions and religions. The western history has also been through the age of turmoil with reformations and counter reformations moving towards the age of enlightenment that marks the beginning of modern art between the end of $18^{\text {th }}$ century and the beginning of $19^{\text {th }}$ century. Before this age art was used for the execution of religious subjects where the individual and intellectual approach of human beings was not given importance as a subject of art. After the age of enlightenment, the multidimensional and transitional phases were very well expressed through the perception of different western and European artists. This was the age of self-realization, uprising, individualization, awareness that opened up realistic metaphors, egalitarianism, fight for their own rights. All of this could be observed while seeing the works of Neo-classical artists that provides the roots for realism, rationalism and socialism. In the perception of Robert Motherwell, "Most paintings in the European tradition were painting the mask. Modern art rejected all 
that, our subject matter was a person behind the mask". ${ }^{12}$ David was a revolutionary artist of Neo-Classicism and his paintings Oath of the Horatii (fig 8), Death of Socrates and Death of Marat primarily worked for the uprising of bourgeois class for the sake of patriotism; these were meant for giving a moral lesson to the society as a whole. The underneath story was very well expressed by the artist having all the flavors to enhance patriotic aspect.



Source: http://www.usc.edu/schools/annenberg/asc/projects/comm 544/library/images/143.jpg (accessed on $5^{\text {th }}$ April, 2018)

Figure 8 Oath of the Horatii by French artist Jacques Louis David, 1784

This approach of stringing connection of art with the present scenario and happenings in the history of the world was further highlighted in the works of other western artists like Gericault, Delacroix, Goya, Constable, Courbet, Millet, Daumier, Picasso, Jacob Lawrence and many more. The work of all these artists was representational and was able to convey the underlying narrative behind the production of work. The Raft of the Medusa by Gericault (1791-1824) was a revolutionary subject matter through which an important incident of history was documented in the form of painting (fig 9).

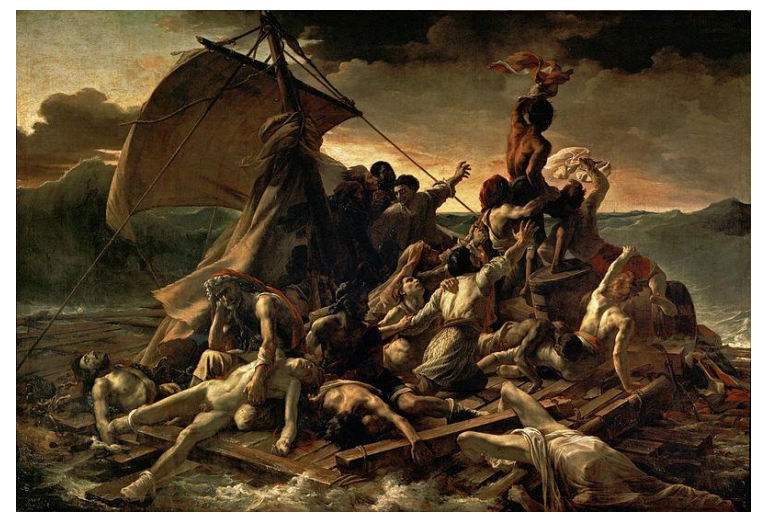

Source: http://deskarati.com/wp-content/uploads/2011/12/Raft _of_the_Medusa.jpg (accessed on $5^{\text {th }}$ April, 2018)

Figure 9 Raft of the Medusa by French artist Theodore Gericault 1818-1819

\footnotetext{
12. Lois Fichner-Rathus. Understanding Art, $6^{\text {th }}$ Edition (London: Wards Worth Thomson Learning, 2001), 427.
}

This painting provides the first reference of art being used as a poster campaign to highlight the negligence of government. ${ }^{13}$ The ship with more than 1500 passengers sunk and out of them only 15 survived. This painting serves as a symbol of pathos and despair and has attained great importance in the history of revolutionary art works. Moving forward, Delacroix's (1798-1863) painting Liberty leading the People also expressed an important episode from history towards the freedom to speak and act, where for the very first time a female figure was executed as the focal point of the painting, while leading a group of men (fig 10). The figure of female is represented here as a symbol of liberty/freedom. This narrates the advancement of human intellect and acceptability in the modern age. Artists were trying to imitate the contemporary time they were living in, where nature proves to be the integral unifying factor and inspiration behind all art forms. Francisco Goya (17461828), a Spanish painter also documented an event of bloodshed which he himself witnessed in the streets of Madrid and communicates with the power of his brush the brutal acts by the Government of Napoleon III in Spain. The painting entitled 3rd of May 1808 illustrates the scenario of that time (fig 11).

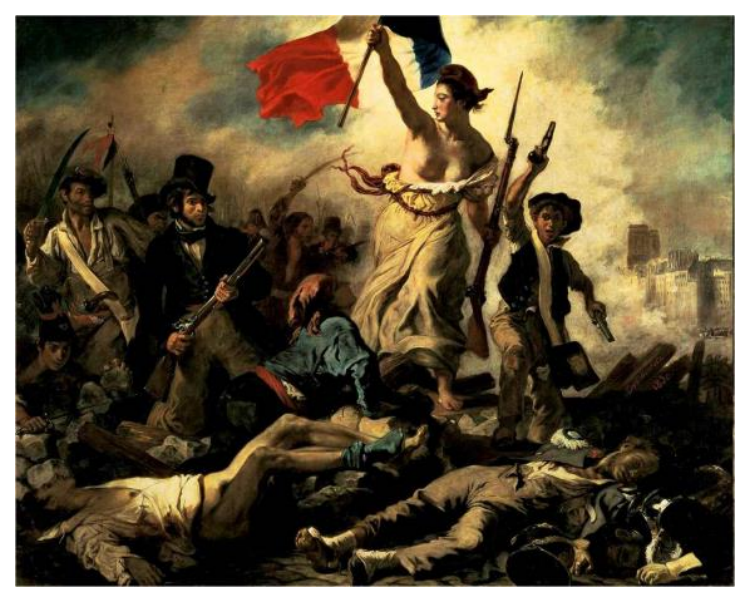

Source: http://uploads4.wikipaintings.org/ images/ eugenedelacroix/the-liberty-leading-the-people-1830.jpg (accessed on $10^{\text {th }}$ April, 2018)

Figure 10 Liberty leading the People by French painter Delacroix 1830

Besides these examples of artworks, no doubt the perception and understanding of art varies in its content, though its function is to express a story whether conceptual or not, representational or nonrepresentational. Art is not all the time as simple for the sensory understanding of human beings, sometimes the flight of artist's imagination became a mystery to solve or unveil. It is the most convincing medium to address harsh and bitter realities in an expressive manner. "The scheme of art is to revolutionize and improve the world". ${ }^{14}$

\footnotetext{
13. Amjad Pervaiz, interview by Farah Khan, $7^{\text {th }}$ February, 2014.

${ }^{14}$. Donald Preziosi. Claire Farago. Art is Not What You Think It Is, $2^{\text {nd }}$ Edition (Chichester: Blackwell Publishing, 2012), 1.
} 


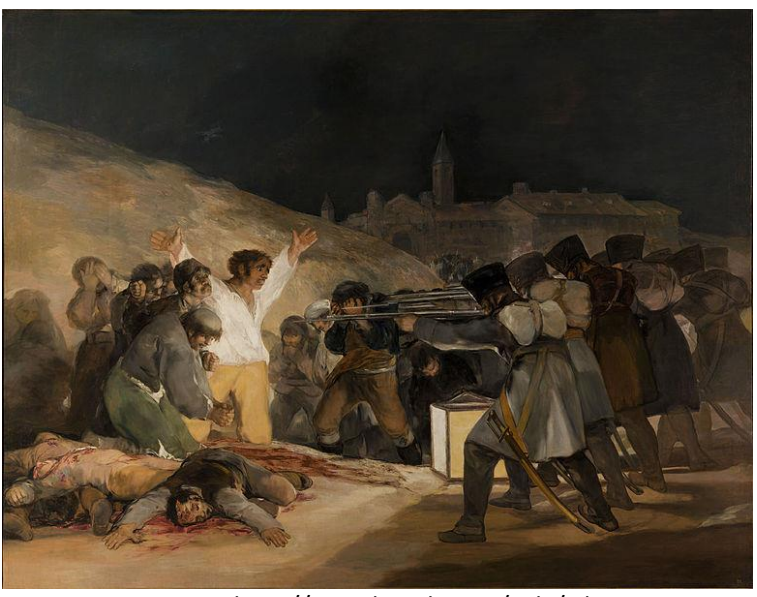

Source: http://en.wikipedia.org/wiki/File:

El_Tres_de_Mayo,_by_Francisco_de_Goya,_from_Prado_thin_black_ma rgin.jpg (accessed on $15^{\text {th }}$ April, 2018)

Figure $113^{\text {rd }}$ of May 1808 by Spanish Painter Francisco Goya 1814

Though, as it has been mentioned earlier that art has been utilized in the western world for highlighting the religious fervor till $18^{\text {th }}$ century. It was used for spiritual personification and as a source of gratification and unification. But with the passage of time and gradual change in human acceptance, the purpose of art widened immensely. It was allowed to utilize for unveiling the visible, for the restoration of traditional and cultural norms, for the preservation of metaphysical experiences through transcendental metaphor, the language of which could be realistic, abstract, semi-abstract, symbolic, objective, or subjective etc. The contemporary world of art has widened the scope of representation. The present-day idea of art is mainly to develop a dialogue between artwork and the viewer where artist attained secondary position and the dialogue gained primary substance.

In the modern age, the dialogue has changed to what kind of practical and visual experience the artist and viewer gained while making or seeing art. Focusing on the experience of art makes it clear that, primarily, art is a source of visual communication. Artists while creating a work of art, produce something for others to see, learn, realize and share. "The study of this communication between the artist and the viewer through the medium of the artist's signs and symbols has been called semiotics". ${ }^{15}$ Art is likewise a scheme of emblematic statement too which expresses what the eyes perceive. ${ }^{16}$

According to Quddus Mirza "a work of art is suspended between two kinds of concepts-a preliminary thought that causes its conception and construction, and the secondary concept generated after its completion that is perceived, interpreted and understood by the

15. Thomas Buser. Experiencing Art Around Us $2^{\text {nd }}$ Edition (London: Wards worth Thomson Learning, 2006), 19.

${ }^{16}$. Ibid, 22. viewers". ${ }^{17}$ Artist is all the time trying to translate and interpret the physical world around him into different concepts, making a series of connectivity with the infusion of his experiences. These experiences are also rooted with the narrative account of the artist's thought. Art is actually the documentation of its own time as Gustave Courbet (1819-1877), an artist of realism believed that "No period should be produced except by its own artists, the objective of the artist is to translate the customs, the ideas, the appearance of his own epoch in his art". ${ }^{18}$

Painting is a dialogue between art and nature where artist acts as an interpreter. Nature provides the main source of inspiration where the concept of realization of sensation became important. As Cezanne once said "If the strongest feeling for nature and I have that vividly is the necessary bases for all artistic conception, on which rests the grandeur and beauty of all future works; the knowledge of the means of expressing our emotions is no less essential and is only to be acquired through very strong experience". There are numerous ways of communication or expressing the core essence behind the spectacles of art product. A number of artists have witnessed the same mode of expressiveness, as Georgia O' Keefe (1887-1986) said "I found I could say things with color and shapes that I could not say in any other waythings I had no words for". After analyzing this statement of the American artist, it could be proclaimed that unheard or silent stories could also be delivered and addressed through the idiom of art in a harmonious manner.

The account of any context also varies in its pictorial representation, which is sometimes realistic and sometimes metaphorical. Metaphorical connotations in art direct towards artists personal reverberation. They facilitate the viewer to think beyond the conventional display and explanation of the way things appear. These metaphorical suggestions are indirectly associated with cultural notions, aesthetic abilities and symbols. "If we compare them, then we will be able to find that they share deep connections with the prevailing stories, traditions of a community". ${ }^{19}$ The intension should be there to unveil the visible dialogue.

Artist is considered to be the key agent for the representation of art; the intrinsic and extrinsic approach is also prevalent in the works of artists. Character of diverse elements whether visible or non-visible direct towards a story having mystic approach which is perceived by the artist according to his personal creative exhibition of expression. It is a matter of visualization and seeing, i.e., how to perceive, how to read, how to interpret and comprehend and most importantly how to develop a strong connection among all? The concept of

\footnotetext{
17. Quddus Mirza, "Art as Idea", (Lahore: The Nation, $5^{\text {th }}$ April 2013), 36.

${ }^{18}$. Shahida Manzoor, interview by Farah Khan, $28^{\text {th }}$ March, 2015.

19. Joanne Raheb-Mol. Art and Mind (Australia, South Melbourne: Oxford University press, 1998), 45
} 
realization of sensation is also prevalent in some artworks.

The purpose of art is about discovering meanings in our life. The renowned Greek philosopher Aristotle once said that people need to realize all that happens in their societies and they must communicate their thoughts with each other. "Many images and objects show us that art can reflect a whole range of worthwhile and relevant ideas, aims and interests". ${ }^{20}$ Art is the most influential instrument to address different issues. As Pablo Picasso (1881-1973) said that "painting is not meant to decorate apartments, it is an instrument of war for attack and defense against the enemy". So, in this context, harsh and loud realities could be addressed in a humble manner. The story that is associated with Guernica (fig 12), a painting painted by Picasso also address the fundamental cause of destruction prevailing in the society of that time which was illustrating the brutal act and bombing that ruined the complete scenario during Spanish civil war. The painting communicates through a loud gesture and after the execution of that work when the ruling power got information regarding the execution of the factual scenario; corpses were directed to examine his place. When they visited his place, found the painting and asked him have you painted it? The artist replied no you have painted it, not me this is what the ruling power has done, if just replicated it. ${ }^{21}$ It was a thought-provoking documentation of human brutality which described the horror of war and bombing in the machine age.

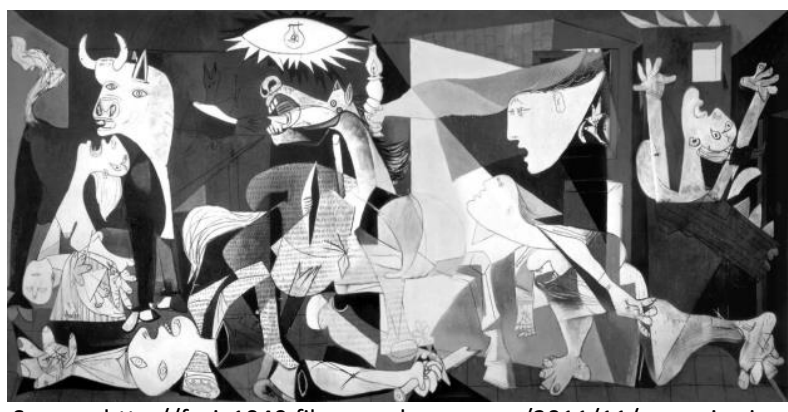

Source: http://fasix1040.files.wordpress.com/2011/11/ guernica.jpg (accessed on $18^{\text {th }}$ April, 2018)

Figure 12 Guernica by Spanish painter Pablo Picasso 1937

There were artists who also tried to document their reactions after having conversation with the nature in the visual language. Something they were not able to express verbally, describes them in their visual expression. As Henri Matisse (1869-1954) once said that "the essential thing is to spring forth, to express the bolt of lightning one's senses upon contact with a thing. The function of the artist is not to translate an observation but to express the shock of the object on his nature; the shock, with the original reaction".

Art is about documenting; revealing and remembering personal experiences and it also document

\footnotetext{
20. Joanne Raheb-Mol. Art and Mind (Australia, South Melbourne: Oxford University press, 1998), 2.

${ }^{21}$. Arif Khan, interview by Farah Khan, 30 ${ }^{\text {th }}$ March, 2014.
}

socio-political experiences. Art has always been used as a powerful medium that has all the potentials to change society's way of thinking. The works of George Grosz (1883- 1959), Jacob Lawrence (1917-2000) provides a series of different settings illustrating the socio-political history of their times. Jacob Lawrence was an American artist who has documented the African-American life and has produced sixty artworks based on the great migration series. Thirty of his works are displayed in Phillips Collection (Washington DC) and the other remaining are on display at Museum of Modern Art (New York). In the migration series, he focused on the mass departure of Afro-Americans who in search of a better life moved towards the North of America (fig 13). The artist preserved a chapter of American history in his individual language of expression in terms of addressing the prevailing scenario of his age.

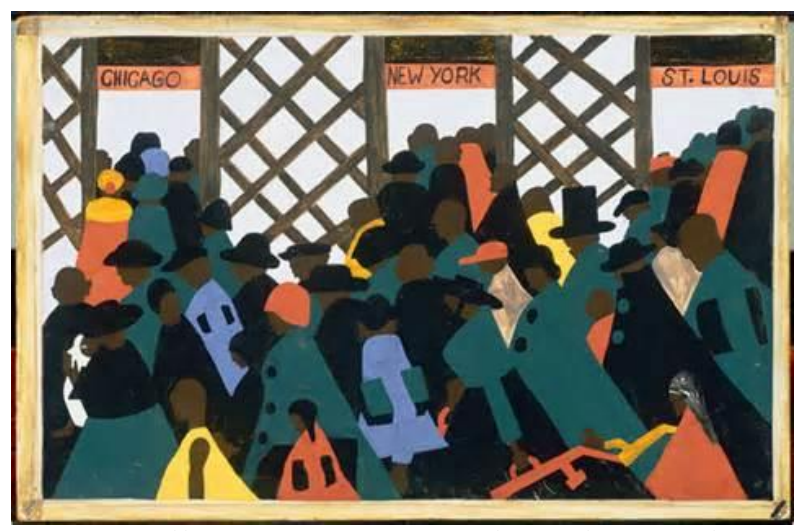

Source: http://www.phillipscollection.org/images/ collection/jacoblawrence-migration-panel-1.jpg?preset=ss (accessed on $18^{\text {th }}$ April, 2018)

Figure 13 The Migration Series by Jacob Lawrence 1941

Kathe Kollwitz (1867-1945) was another German artist who tried to express the intense account of the tragedy of war and of human condition in the first half of the $20^{\text {th }}$ century. One of the etchings by the artist entitled Woman with dead Child (fig 14) expressed the sufferings of people which they faced during the World War II. These artists not only expressed their feelings and sensations but also documented history. Though artists were experimenting and exploring different means of expressions in the $20^{\text {th }}$ century after World War I and II, the reception of art also went through a period of transformation. When Dadaism was introduced, it transformed the visual presentation of the art works and challenged the viewer's acceptance regarding art. This was the first step towards present day formalism. Everything in art got permitted. "What modern art means is that you have to keep finding new ways to express yourself, to express the problems, that there are no settled ways, no fixed approach. It is the modern human condition". 22

\footnotetext{
${ }^{22}$. Lois Fichner-Rathus. Understanding Art, $6^{\text {th }}$ Edition (London: Wards worth Thomson Learning, 2001), 491.
} 


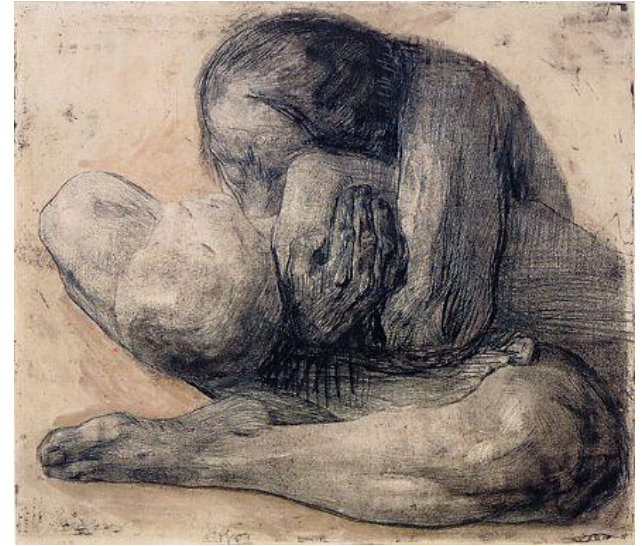

Source: http://en.wikipedia.org/ wiki/File:Kollwitz.jpg (accessed on $20^{\text {th }}$ April, 2018

Figure 14 Woman with dead Child by German artist Kathe Kollwitz 1903

It has also been said that art helps to express the transcendental flight or story of the maker besides the existent reality around him. Vassily Kandinsky, an artist of expressionism from the group blue riders wrote in his book Concerning the Spiritual in Art that "beauty arises from inner psychic necessary, color is the keyboard. The eye is the hammer, the soul with a piano having many strings. The artist is a hand while touching this or that key, makes the soul vibrate". ${ }^{23}$

All works of art from whatsoever period they belong, express enduring values and if they own the quality of life, they became eternal in their appeal. ${ }^{24}$ All the examples of artworks that have been mentioned earlier acquire great importance in history as they unveil the unseen stories from the chapters of history. In the words of Phillip Otto Runge, "works of art all through the ages show us in the clearest fashion how mankind has changed, how a stage that has once appeared never reappears". 25

Lionel Trilling once said that "the discussion of art is a human activity quite as natural as the creation of art". After analyzing different school of thoughts representing different episodes of human history, it is important to analyze the trends of communication in the Art of Pakistan. In Pakistan the history of art is quite different from the history of the western world, though a number of artists have received inspirations from the modern and contemporary trends of European painting but the history of art in Pakistan has not seen such phases of turmoil as the western world has witnessed. Artists are working under different school of thoughts including landscape painting, cultural or traditional painting, historical paintings, miniature paintings, socially conscious, nonobjective, abstract, and calligraphic paintings etc.

\footnotetext{
23. http://www.bookrags.com/studyguide-concerning-the-spiritual-inart/quotes.html

${ }^{24}$. Barbara Whelpton. Art Appreciation: Made Simple (London: W.H. Allen, 1970), 5.

${ }^{25}$. Lois Fichner-Rathus. Understanding Art, $6^{\text {th }}$ Eedition (London: Wardsworth Thomson Learning, 2001), 47.
}

The pioneering figures of Pakistani art Ustad Allah Bux (1885-1978) and Abdur Rehman Chughtai (1894-1975) were known for their romantic expression in painting that was flavored with the infusion of storytelling. Heer and Ranjha, a painting by Ustad Allah Bux narrates the indigenous tale of Punjab with the inclusion of romantic essence, the artist has tried to document and recount one episode from the folk story (fig 15). Their costume represents the traditional styles of Punjabi land. Besides this style of painting, he was known for his mythological paintings like that of Tilism-e-hosh-ruba which is flavored with the flavors of fantasy and stage like setting (fig 16).

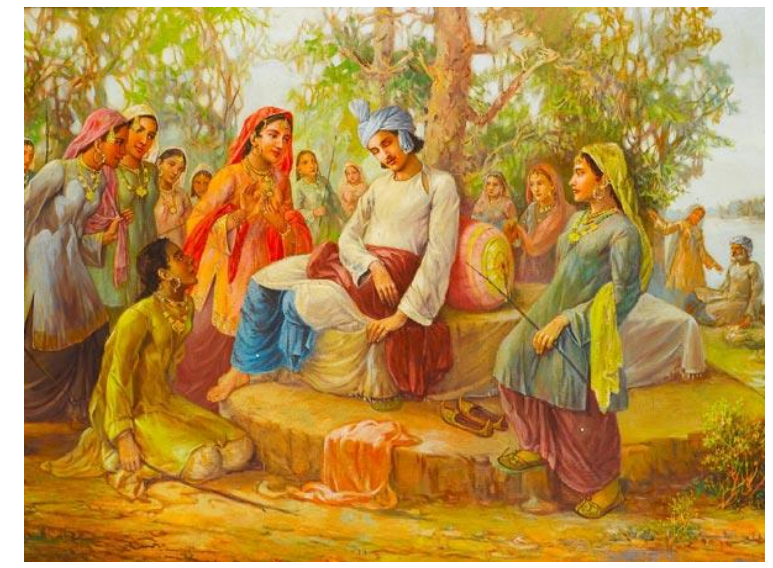

Source: https://www.bonhams.com/auctions/18600/lot/109/ (accessed on $27^{\text {th }}$ April, 2018)

Figure 15 Heer and Ranjha by Ustad Allah Bux

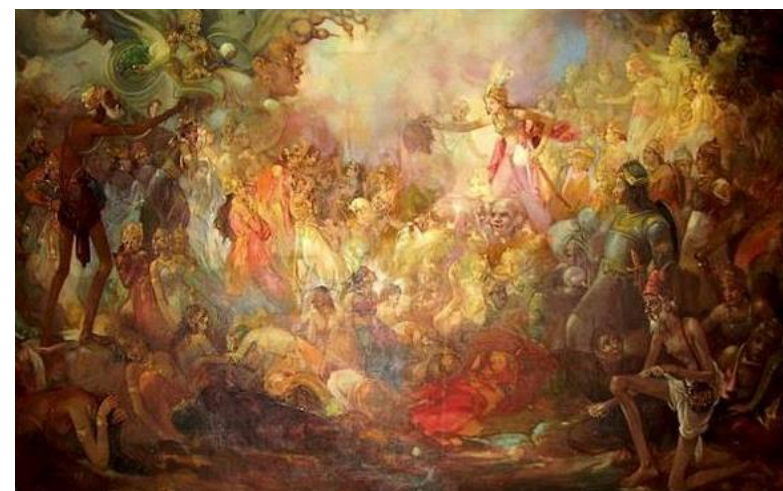

Source: S. Amjad Ali. Painters of Pakistan Islamabad: National Book Foundation, 2000, 79.

Figure 16 Tilism-e-hosh-ruba by Ustad Allah Bux

The works of Chughtai were mostly based on the illustrations of poetry and literature. Most of his work mirrors Mughal aesthetics with emphases on the literary examples of Urdu and Persian poetry specifically of Muhammad Allama Iqbal, Mirza Ghalib and Omar Khayyam. Shah Jahan and Ustad Ahmad Mimar is one of his paintings that illustrates and mirrors an event from the Mughal time period (fig 17). Though there is no specific socio-political or critical historical account in their works, and they were purely meant for the purpose of pleasure seeking but still they were addressing a number 
of diversified stories from the indigenous culture in the language of visual art.

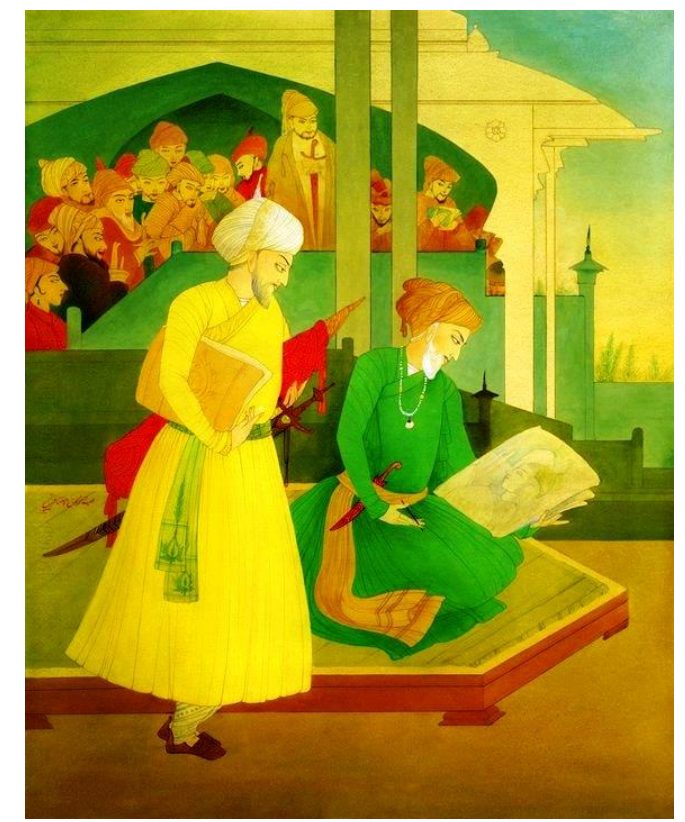

Source: http://farzana.files.wordpress. com/2010/10/abdurrahman-chughtai-5-shah-jahan-and-ustad-ahmad-mimar.jpg (accessed on $25^{\text {th }}$ April, 2018)

Figure 17 Shah Jahan and Ustad Ahmad Mimar by Abdur Rahman Chughtai

After the time of 1960 's, a number of artists started striving to produce meaningful art. This was the time when artists like Shakir Ali, and Zubeida Agha brought with them the western approach and influences of modern painting and started working under cubist style. It was the first shift towards the incorporation of modern influences of different art movements in the works of Pakistani painters, though Allah Bux was also inspired by Pre-Raphaelites and western treatment of skies. He also incorporated these influences into his work, the best example of which could be seen in a painting entitled Sohni Mahiwal which is currently on display at Alhamra permanent Art gallery Lahore. Moving forward there is a vast list of those artists who have tried to communicate with the viewers through the idiom of their art works.

Anna Molka Ahmad is one of those artists who have captured different experiences of Pakistani culture and traditions in her paintings. Though her expression was loud and technique was similar with that of the modern art world, but she also captured the realistic scenes of Punjabi peasantry life, rustic land, philosophical paintings, and episodes of partition, and of flood. ${ }^{26}$ Besides these subjects, her work includes religious paintings like tenth of Muharram and Khana Kaba etc, these were executed with her bold expressionistic palette. In the painting of Muharram, she has tried to capture the religious fervor of the Shiite community in the narrow streets of interior Lahore (plate 18). The zest and vigor could easily be

26. S. Amjad Ali. Painters of Pakistan (Islamabad: National Book Foundation, 2000), 96. examined while looking at the painting. She was the one who encouraged her art students to restore the indigenous cultural essence in their work instead of using alien atmosphere they have never witnessed. She wanted them to represent their native land, its true picture and the colors of Punjab. She used to say that an artist is a psychologist in paint. ${ }^{27}$ Artist is supposed to communicate and address through his art works with the viewers at large.

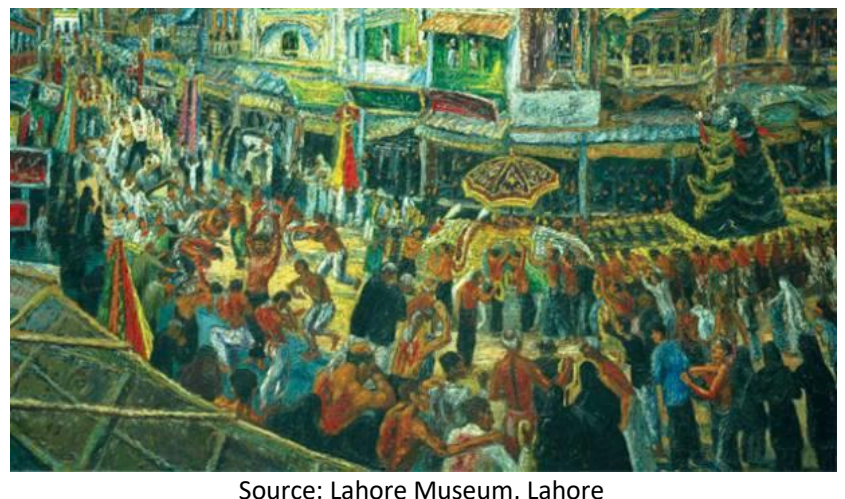

Figure 18 Tenth of Moharram by Anna Molka Ahmad

The narrative account of Pakistani art found it's another string of connectivity in the works of Sadequain. He was one of those artists who have tried to translate their thoughts and feelings in a bold manner. Inspired by the philosophy and poetry of Allama Iqbal and Faiz Ahmad Faiz his work serves as illustrations with the infusion of his self-created imagery highlighted with the exaggerated form of cactus and of human figures. Though he was inspired by Picasso but maintained his own identity as an artist. One of his Murals that was placed at the ceiling of Lahore Museum entitled Evolution of Mankind (fig 19), temporarily removed for restoration, expressed the struggle of human beings since the creation of the universe. Symbolic visual language was also used to make the work stimulating. Sadequain is known for his calligraphic paintings as well, this was the time of Zia-ulHaq's dictatorship when figurative art was banned and as a result calligraphy and calligraphic art got appreciation. ${ }^{28}$ Being Muslims it is our firm belief that calligraphy is meant for didactic purpose, it communicates the hidden essence behind the Arabic letters, and religious fervor is at its peak behind its execution in the Muslim world. He amalgamated the visual forms inspired by the natural world with the infusion of calligraphic text in most of his paintings. Though Sadequain tried to use calligraphic text in traditional manner, but there were some other promising artists like Anwar Jalal Shemza who experienced calligraphy in entirely different fashion.

\footnotetext{
27. Nasim Akhtar Saeed, interview by Farah Khan, $24^{\text {th }}$ April, 2015.

${ }^{28}$. Quddus Mirza, interview by Farah Khan, $6^{\text {th }}$ March, 2014.
} 


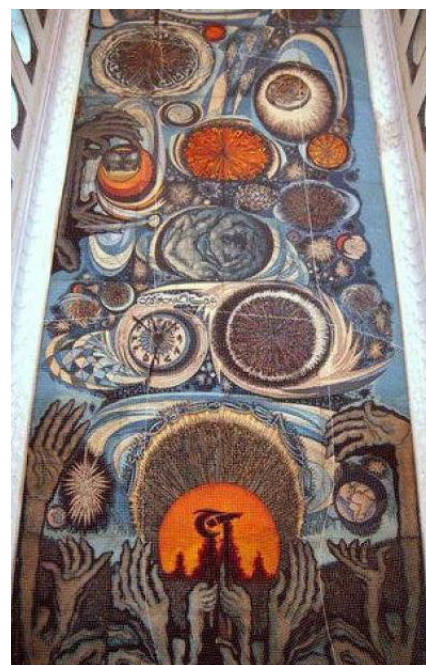

Source: http://www.thehindu.com/opinion/op-ed/crossborder-projectto-save-a-pakistani-art-treasure/article35142.ece (accessed on $2^{\text {th }}$ May, 2018)

Figure 19 Mural entitled Evolution of Mankind by

\section{Sadequain}

Shemza is known as a creative mind, and has used symbolism in calligraphic art. After receiving his degree from NCA he moved towards London for receiving further education from the Slade School of Art. Being in the foreign world he incorporated in his work the calligraphic forms, Islamic carpet designs and Mughal Architectural elements. These elements found new artistic expression in his work, narrating the rich cultural roots of the artist and his homeland. The root series provides all the references of these inspirations (fig 20) that makes him different from his contemporary artists. This series expressed the unique connection of the artist with his personal belongings where the conscious and the subconscious mind helped him to narrate his sensations with individualistic approach.

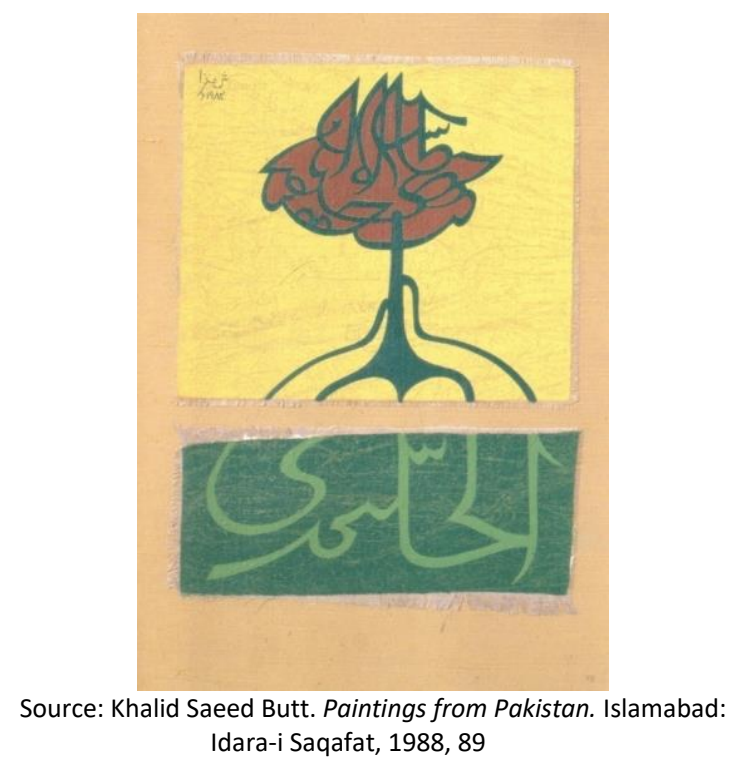

Figure 20 Anwar Jalal Shemza, Roots Series, 1984, size unknown, mix media on canvas, private collection.
Zahoor-ul Akhlaque was another unique artist who has recorded history while communicating through a conceptual dialogue. "In some of his paintings he has used farmans symbolizing the royal seal of authority". ${ }^{29}$ In one of his paintings entitled Remembrance of a famous old Miniature (fig 21), he has tried to revitalize and restore one of the sections from the Mughal era. Strong connection with history could be easily examined in the works of these artists who besides being the predecessors of modern conceptual painting, pays homage to their glorious heritage as well. Their work provides the narrative account of history and culture. Askari Mian Irani also tried to incorporate in his work the traditional elements. He was greatly inspired by the rich heritage of sub-continent most eminently Muslim/Mughal monuments, miniature paintings, Islamic geometrical designs normally used in the Mughal architectural decoration. He also reveals a chapter of history, revive it with his colorful palette and communicated with the viewers through his unique expressive style of painting (fig 22).

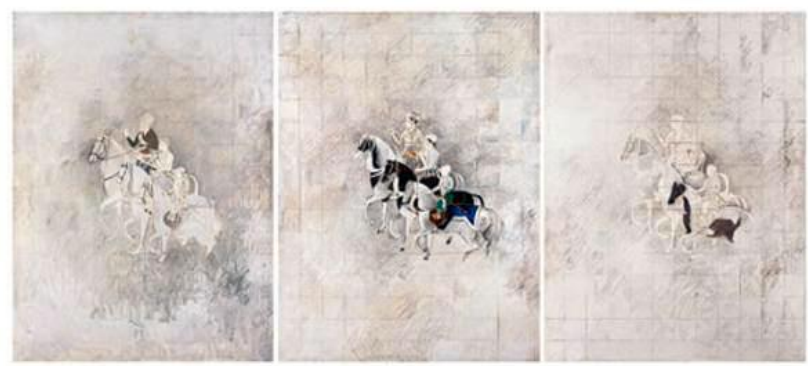

Source: http://paintersofpakistan.files.wordpress.com/2014 /03/za1.jpg (accessed on $28^{\text {th }}$ May, 2018)

Figure 21 Remembrance of a famous Mughal miniature by Zahoor-ul Akhlaque

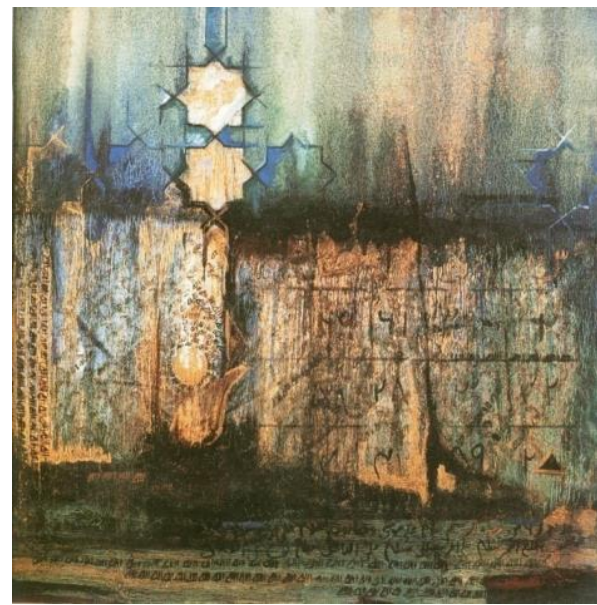

Source: Amina Hassan. ed. Askari: The Jeweller in Paint Lahore: Lahore Arts Council, 1998, 99

Figure 22 Askari Mian Irani, Naqsh-i-Sitar, 1989, mix media on canvas, $23^{\prime \prime} \times 23^{\prime \prime}$, private collection.

29. Akbar Naqvi, Image and Identity: Fifty Years of Painting and Sculpture in Pakistan. (Karachi: Oxford University Press, 1998), 459. 
There are some socially conscious artists as well who have tried to address socio-political issues and related stories of the chaotic period, they themselves experienced and shared in visual form with the mass audience in a vibrant manner. The list of these artists includes Salima Hashmi, A.R. Nagori, Jamal Shah, Rabia Zuberi, Ali Azmat, Imran Qureshi, Shazia Sikander, Sobia Ahmed, etc. Salima Hashmi has raised her voice for addressing socio-political and feminist issues of her time. She used a loud gesture in her paintings while focusing on the conceptual approach. She expressed her profound affiliation with the society being a part of it (fig 23). A.R. Nagori is the one who has pioneered socio-political art in Pakistan. His paintings were addressing harsh realities and political issues from the Pakistani history. Each and every piece of his work was embedded with a question of existence, it was more like a critical analysis by the artist rather than simply an expression. Lal Masjid series examines the critical ambiance and highlight the underlying concealed concept (fig 24). He is one of those artists who have been the victims of Zia-ul Haq's dictatorship and was imprisoned a number of times because of his direct visual dialogue he used to develop through his paintings.

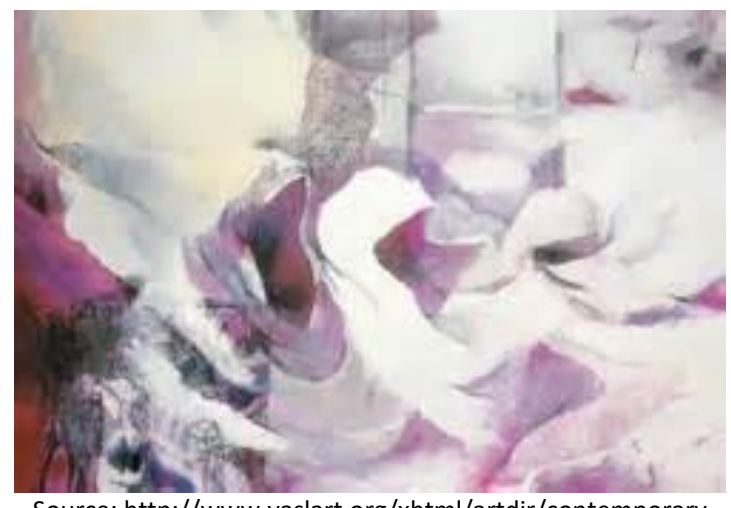

Source: http://www.vaslart.org/xhtml/artdir/contemporary /List\%20S/salima_hashmi/ (accessed on $28^{\text {th }}$ May, 2018)

Figure 23 In Spite of Wrath 2 by Salima Hashmi, 1987

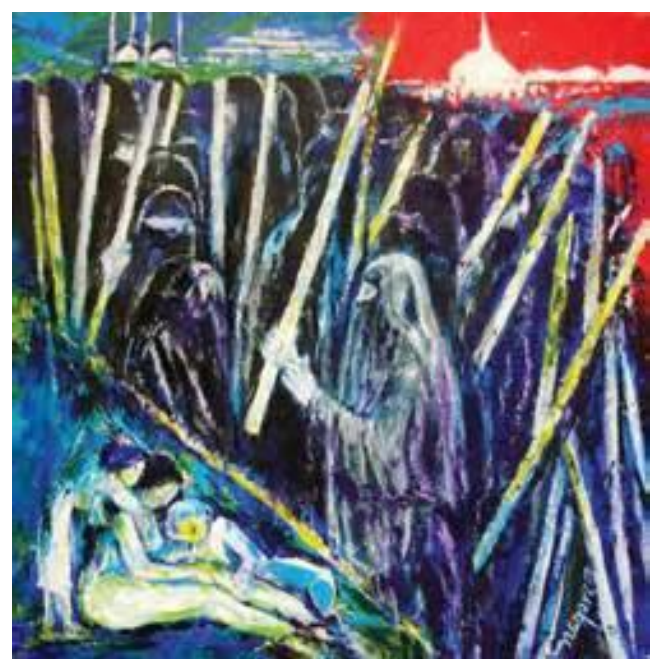

Source: http://himalmag.com/userfiles/image/april09/a_r_nagori_lalmasjid.jpg (accessed on $5^{\text {th }}$ June, 2018)

Figure 24 Lal Masjid series by A.R. Nagori
Iqbal Hussain is among those artists who have recorded their personal experiences being a part of the red-light area of Lahore. Through his work, he tried to communicate the hidden feelings of the ladies from that side. The artist has portrayed those female's sometimes nude and sometimes draped being in their typical environment (fig 25). The overall atmosphere of the paintings and the expressions on the faces of those females narrates their helplessness and sorrow rapped in the compositional frame. The list of Pakistani artists is immensely wide who have contributed and strengthened linkage between the artwork and the community, all have worked to highlight a dialogue through multi-dimensional facets and have registered history in the most powerful visual language of art.

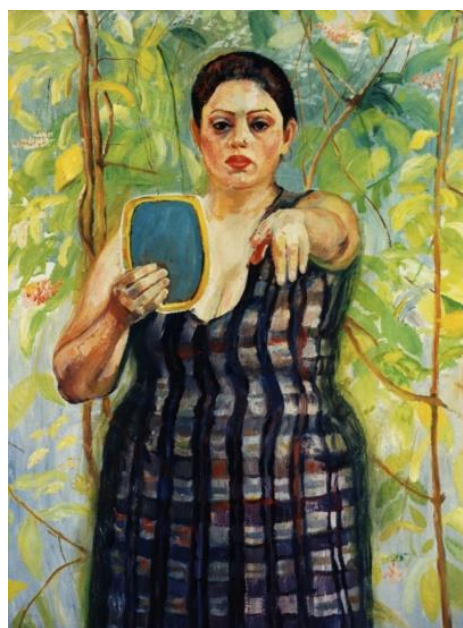

Source: http://tns.thenews.com.pk/art-self-censorship/\#.W_hhQOgzblU (accessed on $6^{\text {th }}$ June, 2018)

Figure 25 Untitled by Iqbal Hussian, 2011

Currently artists like Imran Qureshi, Waseem Ahmed, Farida Batool, Muhammad Zeeshan, Adeela Suleman, Bani Abidi, Ali Azmat, Imran Mudassar, Sobia Ahmed and many more are trying to raise their loud visual voice to address chaotic atmosphere around the globe. As terrorism and violence has become an increasing reality in the lives of Pakistani people and even of people across the world. These artists are busy in expressing the emotional, physical, and psychological disorder prevalent in the current age. Ali Azmat's series of paintings entitled Let a Thousand Flowers Bloom (fig 26) raised a question for existence being in the age of violence and terrorism. A child that is considered to be the most innocent creature on earth is asking for a better life and future, if he will be given time to live on this sphere. Imran Qureshi's installation entitled Blessings upon the Land of my Love (fig 27) speaks through the visual representation of a courtyard space covered with deep floral forms coming out of the bloodshed shown with the splashes of red paint. It simply narrates how a peaceful land has transformed into a volatile ground. 


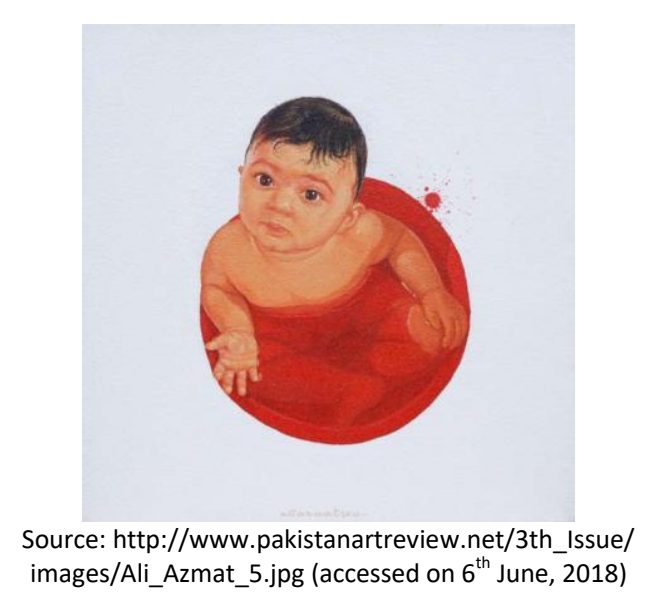

Figure 26 Let a Thousand Flowers Bloom by Ali Azmat, 2011.

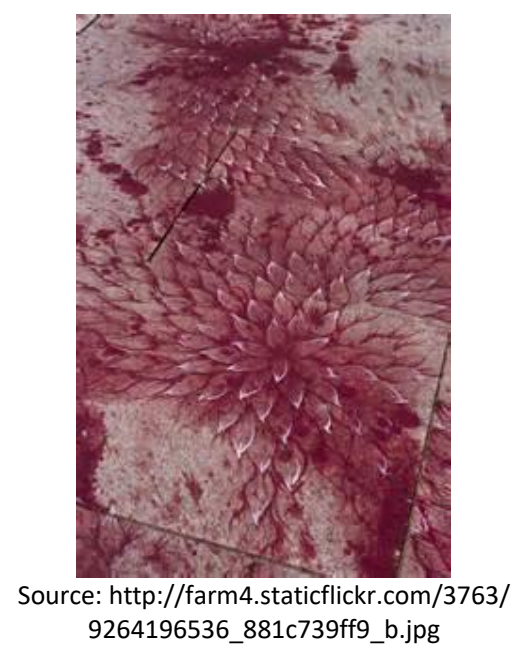

Figure 27 Blessings upon the Land of my Love by Imran Qureshi

\section{Conclusion}

All the examples of artists with their works discussed in this paper, were meant to share that art has remained a strong tool for visual communication where artists worked as interpreters of multiple historical episodes. The aim was to unlock different stories and to bring into the notice of readers that how art evolves in different regions as the documentation of human existence with reference to their philosophies, ideologies, cultural and religious norms and socio-political environment. Undoubtedly, art played enormous role in inspiring the thought-process of people; it emphasized issues and also provided motivation to people as well. This chain of presenting visual narrative account of mankind has broad vistas. Art practice has always served for the documentation of different events around the globe in diversified expressionistic languages. As Hegel says, "a work of art is not for itself but for us, for a public which looks on and enjoys a conversation with everyone who stands in front of it". ${ }^{30}$ A work of art is primarily a question, it is a discourse to the resonant breast and a song to the spirit and souls. ${ }^{31}$ The spectators became partners in a dialogue and play an enormous role in the development of the conversation. Art is an act of addressing subjective processes. Throughout the globe artists from different regions and religions have played vital role in developing communicative linkages between society and art. It is an open debate that will continue till the end of the world. Art is a silent voice that could be heard through strong sensation in all communities of the world. No doubt, it is the strongest source of visual communication that has served as a string of connectivity between the masses since the creation of mankind and will remain so.

\section{References}

[1]. Ali, S. Amjad. Painters of Pakistan. Islamabad: National Book Foundation, 2000.

[2]. Buser, Thomas. Experiencing Art around us $2^{\text {nd }}$ Edition. London: Wards worth Thomson Learning, 2006.

[3]. Butt, Khalid Saeed. Paintings from Pakistan. Islamabad: Idara-i Saqafat, 1988.

[4]. Hassan, Amina. editor. Askari: The Jeweller in Paint Lahore: Lahore Arts Council, 1998.

[5]. Hauser, Arnold. The Sociology of Art. London: Routledge and Kegan Paul, 1982.

[6]. Kleiner, Fred S. Christin J. Mamiya. Gardener's Art through the Ages $13^{\text {th }}$ Edition. New York: Thomson Wordsworth, 2005.

[7]. Nairne, Sandy. Art Now: Interviews with Modern Artists. London: Continuum, 2002.

[8]. Naqvi, Akbar. Image and Identity: Fifty Years of Painting and Sculpture in Pakistan. Karachi: Oxford University Press, 1998.

[9]. Neill, Alex. Aaron Ridley editor. Arguing about Art: Contemporary Philosophical Debates, $2^{\text {nd }}$ edition. London: Routledge, 2002.

[10].Pande, Alka. Master pieces of Indian Art. New Delhi: Roli and Janssen, 2004.

[11].Preziosi, Donald. Claire Farago. Art is not What you think it is, $2^{\text {nd }}$ edition. Chichester: Blackwell Publishing, 2012.

[12].Raheb-Mol, Joanne. Art and Mind. Australia (South Melbourne): Oxford University press, 1998.

[13].Rathus, Lois Fichner. Understanding Art, $6^{\text {th }}$ Edition. London: Wards worth Thomson Learning, 2001.

[14].Read, Herbert. Art Now. London: Faber and Faber, 1960.

[15].Rynck, Patrick De. How to Read a Painting: Decoding, Understanding and Enjoying the Old Masters. London: Thames and Hudson, 2004.

[16].Whelpton, Barbara. Art Appreciation: Made Simple. London: W.H.Allen, 1970.

[17].http://www.bookrags.com/studyguide-concerning-thespiritual-in-art/quotes.html

[18].http://en.wikipedia.org/wiki/Hinduism\#cite_note-trad-2

[19].https://www.bonhams.com/auctions/18600/lot/109/

[20].http://www.artnowpakistan.com/InFocus/ArtintheTime ofTerrorTheRoleoftheArtist-105.html\#.U13gOoFdVi1

${ }^{30}$. Arnold Hauser. The Sociology of Art (London: Routledge and Kegan
Paul, 1982), 437. 